\title{
Pengaruh Bauran Pemasaran Terhadap Keputusan Pembelian Mahasiswa Pada Kedai Kopma $\mathrm{Al}$ - Iqtishad IAIN Palu
}

\author{
Abdul Azis R ${ }^{1 *}$ Irwam Pakkawaru², Uswatun Hasanah ${ }^{3}$, Ibrahim R. Mangge ${ }^{4}$ \\ ${ }^{1}$ Jurusan Ekonomi Syariah, Fakultas Ekonomi dan Bisnis Islam, IAIN Palu \\ ${ }^{2}$ Jurusan Ekonomi Syariah, Fakultas Ekonomi dan Bisnis Islam, IAIN Palu, \\ ${ }^{3}$ Jurusan Ekonomi Syariah, Fakultas Ekonomi dan Bisnis Islam, IAIN Palu \\ ${ }^{4}$ Jurusan Ekonomi Syariah, Fakultas Ekonomi dan Bisnis Islam, IAIN Palu
}

ABSTRAK

Tujuan penelitian ini adalah untuk mengetahuai pengaruh kualitas dan desain produk terhadap keputusan pembelian motor yamaha vixion pada organisasi vixion di kota Palu Lokasi pada penelitian ini di wilaya kota Palu provinsi Sulawesi Tengah. Populasi dalam penelitian ini adalah seluruh anggota organisasi vixion di Kota Palu yang berjumlah 8 organisasi yaituVixion Young Riders Community,Rider Vixion Independen, Yamaha Vixion Club Indonesia, Vixion Jari-Jari Palu Vixion Ruji Squad Palu Celebes Vixion Club Dan Vixion Independen Club yang jumlah keseluruhan anggota282anggota. Teknik pengambilan sampel yang digunakan adalah teknik sample random sampling sebanyak 74 orang, dengan menggunakan rumus slovin untuk menentukan jumlah sampel. Teknik pengumpulan data adalah melalui teknik observasi, kuesioner, dan wawancara. Teknik analisa yang digunakan adalah analisis regresi linear berganda. Hasil olahan statistik yang dibantu dengan program SPSS 21 For Windows, menunjukkan bahwa variabel yang terdiri dari kualitas produk,dan desain secara serempak berpengaruh terhadap keputusan pembelian Motor Yamaha Vixion Studi Pada Organisasi Vixion di Kota Palu.
INFORMASI

ARTIKEL

\section{Katakunci:}

Bauran Pemasaran, Pembelian, Keputusan, Mahasiswa, Koperasi Mahasiswa 


\section{PENDAHULUAN}

Pada era globalisasi yang berkembang pesat saat ini mengakibatkan setiap manusia setiap kali akan mengalami perubahan, baik dalam bidang politik, sosial, ekonomi dan budaya dan juga pengaruh pada pola perilaku pesaing di dalam menjalankan bisnis dan usahanya. Usaha yang dilakukan untuk mencapai tujuan salah satunya melalui kegiatan pemasaran, yaitu proses dimana perusahaan menciptakan nilai bagi pelanggan dan membangun hubungan yang kuat dengan pelanggan dengan tujuan untuk menangkap nilai dari pelanggan sebagai imbalannya. ${ }^{1}$

Pertumbuhan bisnis yang sangat cepat mendorong perusahaan untuk berkompetisi dalam setiap aktivitas perusahaan termasuk dalam bidang pemasaran. Pada bidang pemasaran ini perusahaan melakukan kompetisi diantaranya pada aspek harga, pelayanan, dan merk dari suatu produk. Perusahaan harus selalu waspada terhadap strategi para pesaing yang berusaha merebut pangsa pasar. Penciptaan merk yang selalu dapat diingat oleh konsumen dapat merupakan

\footnotetext{
${ }^{1}$ Anggoro Dwi Kurniawan, “Analisis Pengaruh Produk, Promosi, Harga dan Tempat Terhadap Pembelian Studi pada Kedai Amarta Semarang",Skripsi (Semarang: Universitas Diponegoro Semarang, 2012), (Diakses, 5 Mei 2018).
}

salah satu hal yang membuat konsumen tidak berpindah ke merek lain. ${ }^{2}$

Secara umum pemasaran dapat dikatakan sebagai pola pikir yang menyadari bahwa perusahaan tidak akan dapat bertahan tanpa adanya transaksi pembelian. Perusahaan harus dapat memasarkan barang atau jasa yang diproduksi kepada konsumen agar dapat bertahan dan bersaing dengan perusahaan lain. Menurut Alma, produk merupakan titik sentral dari kegiatan marketing. Semua kegiatan marketing lainnya digunakan untuk menunjang pemasaran produk. Satu hal yang perlu diingat ialah bagaimanapun hebatnya usaha promosi, distribusi dan harga yang baik jika tidak diikuti oleh produk yang bermutu dan disenangi oleh konsumen maka kegiatan marketing mix ini tidak akan berhasil. Jadi disini yang dimaksud adalah perusahaan dengan produk yang paling baik yang akan tumbuh dengan pesat, dan dalam jangka panjang perusahaan tersebut akan berhasil dari perusahaan yang lain. ${ }^{3}$

Promosi merupakan salah satu variabel dalam bauran pemasaran yang

\footnotetext{
${ }^{2}$ Rahmawati, “Analisis Faktor-Faktor Yang Mempengaruhi Ekuitas Merek Untuk Meningkatkan Minat Beli Ulang Studi Kasus Pada Kedai Kopi Dome di Surabaya, ". Http:// www. R Setyaningsih 2008- eprints.indip.ac.id (Diakses 5 Mei 2018).

${ }^{3}$ Buchari Alma, Kewirausahaan Untuk Mahasiswa dan Umum (Edisi Revisi; Bandung: Alfabeta, 2007), 202.
} 
penting dilaksanakan oleh perusahaan dalam pemasaran produk atau jasa nya. Menurut Basu Swasta dan Irawan dalam Kurniawan promosi adalah arus informasi atau persuasi satu arah yang dibuat untuk mengarahkan seseorang atau organisasi kepada tindakan yang menciptakan pertukaran dalam pemasaran. ${ }^{4}$

Harga merupakan unsur bauran pemasaran yang bersifat fleksibel, artinya dapat diubah dengan cepat. Harga juga dapat menjadi indikator kualitas dimana suatu produk dengan kualitas yang tinggi akan berani dipatok dengan harga yang tinggi pula. Harga dapat mempengaruhi konsumen dalam melakukan keputusan pembelian.

Lokasi juga dapat berpengaruh terhadap keputusan konsumen untuk melakukan pembelian baik barang maupun jasa. Lokasi yang mudah dijangkau dan dekat dengan keramaian merupakan lokasi yang tepat untuk suatu usaha, termasuk usaha warung makan atau kedai. Sebelum seseorang atau kelompok memutuskan untuk makan disuatu warung makan atau kedai maka mereka akan mempertimbangkan lokasi kedai tersebut. Sebagian besar orang akan memilih tempat makan yang lebih

\footnotetext{
${ }^{4}$ Kurniawan, A. 2012. Pengaruh Produk, Promosi, Harga, dan Tempat Terhadap Keputusan Pembelian (studi Kasus Pada Kedai Amarta Semarang. Http:// www. AD Kurniawan -2012eprints.undip.ac.id (diakses tanggal 5 Mei 2018)
}

dekat dengan rumah atau tempat kerja mereka. $^{5}$

Terkait dengan kegiatan pemasaran, di kampus IAIN Palu berdiri sebuah kedai yang jugamelaksanakan kegiatan pemasaran dan juga menerapkan sistem bauran pemasaran. Kedai ini bernama Kedai KOPMA Al-Iqtishad IAIN Palu.

Kedai KOPMA merupakan salah satu kedai yang ada dilingkungan kampus IAIN Palu yang menyediakan berbagai menu makanan dan minuman untuk mahasiswa IAIN Palu khususnya dan masyarakat umumnya. Sebagai salah satu kedai dari beberapa kedai yang ada di lingkungan kampus, tentunya Kedai KOPMA menjadi alternatif bagi para mahasiswa yang membutuhkan makanan atau minuman. Ada beberapa varian menu makanan dan minuman yang dimilki oleh Kedai KOPMA diantaranya, makanan berat terdiri atas 10 varian menu, untuk makanan santai ada 7 varian, sedangkan untuk minuman terdiri dari 22 jenis minuman yang di tawarkan. Tidak hanya itu, Kedai KOPMA juga menyediakan fasilitas perpustakaan mini yang berada di pojok kedai. Mahasiswa dapat membaca beberapa buku bacaan yang disediakan sembari menunggu pesanan mereka datang. ${ }^{6}$

${ }^{5}$ Ibid., 5.

${ }^{6}$ Asriyani, Pengurus Kedai KOPMAAlIqtishad IAIN Palu Periode 2016-2018, "wawancara", di Kedai KOPMA, 11 Juli 2018. 
Kedai KOPMA memiliki tenaga kerja yang berlatar belakang mahasiswa yang tidak lain adalah mahasiswa IAIN Palu yang tergabung dalam pengurus Kedai KOPMA Al-Iqtishad IAIN Palu.

Sejak didirikannya pada bulan Mei 2015 sampai tahun 2017 Kedai KOPMA mengalami fluktuasi omzet penjualan, bahkan pengurus mengatakan mengalami penurunan omzet penjualan. ${ }^{7}$ Selain itu, akhir-akhir ini pengunjung yang datang ke Kedai KOPMA kebanyakan hanyalah anggota Koperasi Mahasiswa Al-Iqtishad IAIN Palu saja. ${ }^{8}$ Berikut di bawah ini tabel data penjualan Kedai KOPMA Al-Iqtishad IAIN Palu dari tahun 2015 sampai dengan tahun 2017.

\section{TINJAUAN PUSTAKA}

\subsection{Pengertian Pemasaran}

Pengertian pemasaran selalu berkembang dari waktu ke waktu, dimulai dari pengertian sederhana sampai dengan pemasaran dalam lingkungan persaingan bisnis yang semakin modern dan kompetitif.

Kotler dan Keller menyatakan bahwa:

"Marketing is an organizational funciont and a set processes for

${ }^{7}$ Kamelia, Koordinator Bidang Usaha KOPMAAl-Iqtishad IAIN Palu Periode 2016-2018, "wawancara", di Kedai KOPMA, 10 Juli 2018.

${ }^{8}$ Ririn Syuhada, Pengurus Kedai KOPMA Al-Iqtishad IAIN Palu Periode 2018-2019, "wawancara, di Kedai KOPMA, 11 Juli 2018. creating, communicating and delivering value to customers and for managing customer relationship in way that benefit the organization and in stake holders"

Artinya:

"Pemasaran ialah fungsi organisasi dan satu set proses untuk menciptakan, mengkomunikasikan, dan menyampaikan nilai kepada pelanggan yang memberikan keuntungan bagi organisasi dan pihak-pihak yang berkepentingan bagi organisasi". ${ }^{10}$

Selain dari segi konvensional pengertian pemasaran dari segi syariah juga di kemukakan oleh Kertajaya. Secara umum Kertajaya mengemukakan bahwa:

"Syariah markting is a strategic business discipline that the directs process of creating, offering, and exchanging value from one inisiator to its stakeholders and whole process should be in accordance with muamalah principle in Islam"11

Artinya:

"Pemasaran syariah adalah strategi bisnis, yang harus memayungi seluruh aktivitas dalam sebuah perusahaan, meliputi seluruh proses, menciptakan, menawarkan, pertukaran nilai, dari seorang produsen, atau satu perusahaan, atau perorangan yang sesuai ajaran Islam". ${ }^{12}$

${ }^{9}$ Buchari Alma, Doni Juni Priansa, Manajemen Bisnis Syariah Menanamkan Nilai dan Praktik Syariah dalam Bisnis Kontemporer (Edisi Revisi; Bandung: Alfabeta, 2014), 340.

${ }^{10}$ Ibid.,

${ }^{11}$ Ibid., 343.

${ }^{12}$ Ibid., 
Selanjutnya dalam konteks Islam Alma juga memberikan sebuah definisi tentang marketing syariah, marketing syariah merupakan strategi bisnis yang harus memayungi seluruh aktivitas dalam sebuah perusahaan, meliputi seluruh proses, menciptakan, menawarkan, pertukaran nilai, dari seorang produsen, atau satu perusahaan, atau perorangan, yang sesuai dengan syariat Islam. $^{13}$

Pemasaran dalam Islam adalah bentuk muamalah yang dibenarkan dalam Islam, sepanjang dalam proses transaksinya terpelihara dari hal-hal terlarang oleh ketentuan syariah. Sedangkan menurut Kerta Jaya dan Sula, Syariah marketing adalah sebuah disiplin bisnis strategis yang mengarahkan proses penciptaan, penawaran dan perubahan value dari suatu inisiator kepada kepada stakeholders-nya yang dalam keseluruhan prosesnya sesuai dengan akad dan prinsip-prinsip muamalah (bisnis) dalam Islam. $^{14}$

Dari pengertian tersebut dapat diuraikan bahwa pemasaran merupakan usaha untuk memenuhi kebutuhan dan keinginan konsumen terhadap suatu produk dan jasa.Untuk mengetahui kebutuhan dan

\footnotetext{
${ }^{13}$ Buchari Alma, Manajemen Bisnis Syariah (Bandung: Alfabeta, 2009), 258.

${ }^{14}$ Hermawan Kertajaya, Muhammad Syakir Sula, Syariah Marketing (Bandung: PT Mizan Pustaka, 2006), 9.
}

keinginan konsumen, maka setiap perusahaan perlu melakukan riset pemasaran sehingga bisa di ketahui keinginan dan kebutuhan konsumen yang sebenarnya.

Dapat dilihat perbedaan antara pemasaran konvensional dan pemasaran dalam Islam, dimana perbedaannya terletak pada proses kegiatannya. Jika dalam konvensional proses kegiatannya tidak berlandaskan pada apapun, maka dalam Islam setiap kegiatan pemasarannya harus berlandaskan pada ajaran Islam. Pemasaran Islam percaya bahwa perbuatan seseorang akan dimintai pertanggungjawabannya kelak. Berdasarkan pemaparan diatas dapat diambil kesimpulan bahwa konsep pemasaran setidaknya mengandung tiga unsur, yaitu: orientasi pada konsumen, penyusunan kegiatan pemasaran secara integral dan tersusun, dan kepuasan konsumen. ${ }^{15}$

\section{Landasan Hukum Pemasaran}

Pemasaran dalam pandangan Islam merupakan suatu penerapan disiplin strategis yang sesuai dengan nilai dan prinsip syariah.Kegiatan pemasaran mengandung adanya pertukaran atau transaksi atau disebut sebagai perniagaan.Kegiatan pemasaran juga berorientasi pada konsumennya yang

\footnotetext{
${ }^{15}$ Basu Swashta Darmmesta dan Hani Handoko, Manajemen Pemasaran: Analisis Perilaku Konsumen (Yogayakarta: BPFE, 2013), 6.
} 
dilakukan secara terstruktur dan bertujuan menciptakan kepuasan.

\subsection{Bauran Pemasaran}

Bauran pemasaran

(Marketing. mix)merupakan strategi kombinasi yang. dilakukan oleh berbagai perusahaan daland bidang pemasaran.Hampir semua melakukan strategi ini.Kombinasi yang terdapat dalam marketing mixharus dilakukan secara terpadu.Artinya, pelaksanaan dan penerapan komponen ini harus dilakukan dengan memerhatikan antara satu komponen dengan komponen lainnya.

Sedangkan menurut Kotler dan Keller mengemukakan pengertian bauran pemasaran yaitu:

"Bauran pemasaran adalah perangkat alat pemasaran yang digunakan perusahaan untuk mengejar tujuan perusahaannya."16

Selain itu Kertajaya dan Sula juga memberikan komentar mengenai bauran pemasaran (marketing-mix)yaitu:

"Marketing-Mix yang dimaksud adalah bagaimana mengintegrasikan tawaran dari perusahaan (company's offers) dengan akses yang tersedia (company's acces). ${ }^{17}$

a. Produk (product)
Kotler, menyebutkan konsep bauran pemasaran (marketing mix) terdiri atas empat P (4P), yaitu: ${ }^{18}$

a. Product (produk)

Price (harga) 
Menurut Kotler dan Amstrong dalam Apri, produk adalah semua hal yang dapat ditawarkan kepada pasar untuk menarik perhatian, akuisi, penggunaan, atau konsumsi yang dapat memuaskan suatu keinginan atau kebutuhan. ${ }^{20}$

Dari sudut pandang syariah Kertajaya dan Sula mengemukakan bahwa produk haruslah didasari dengan nilai kejujuran dan keadilan sesuai dengan prinsip syariah.Kualitas produk yang diberikan haruslah sesuai dengan yang ditawarkan.Sangat dilarang menyembunyikan kecacatan yang dimiliki oleh produk yang ditawarkan. ${ }^{21}$

\section{b. Harga (Price)}

Harga menurut Kotler dan Amstrong dalam Apri adalah jumlah yang ditagihkan atas suatu produk barang atau jasa, atau jumlah semua nilai yang diberikan oleh pelanggan untuk mendapatkan keuntungan dari memiliki atau menggunakan suatu produk barang atau jasa. ${ }^{22}$ Menurut Amin Suma harga yaitu:

"nilai barang yang ditentukan atau dirupakan dengan uang, atau alat tukar lain yang senilai, yang harus

\footnotetext{
${ }^{20}$ Apri Budianto, Manajemen Pemasaran (Yogyakarta: Penerbit Ombak, 2015), 180.

${ }^{21}$ Kertajaya, Sula, Syariah, 218.

${ }^{22}$ Budianto, Manajemen, 256.
}

dibayarkan untuk suatu produk atau jasa." 23

Kertajaya dan Sula mengemukakan bahwa harga haruslah didasari dengan nilai kejujuran dan keadilan.Jika kualitas produknya bagus maka, harganya tentu bisa tinggi.Sebaliknya, jika seseorang telah mengetahui keburukan yang ada dibalik produk yang ditawarkan, harganyapun harus disesuaikan dengan kualitas produknya. ${ }^{24}$ Selain itu menurut Ibn Qayyim harga wajib dibatasi dan dipatok sedemikian rupa agar tidak mudah naik dan tidak mudah turun mengingat sifatnya yang akurat dan spesifik.Sebab, bila harga bersifat fluktuatif seperti halnya barang-barang, maka tidak ada artinya lagi kita menetapkan harga penjualan (al-mab'iat) bahkan untuk semua komoditi. $^{25}$

$$
\text { Penetapan harga dalam Islamjuga }
$$
boleh kompetitif, namun dalam menentukan harga tidak boleh dengan cara yang merugikan pebisnis lainnya. Mengambil keuntungan diperbolehkan dalam Islam, akan tetapi mengambil keuntungan tersebut janganlahberlebih-lebihan.

\section{c. Lokasi (Place)}

\footnotetext{
Publishing, 2008), 183.

${ }^{24}$ Kertajaya, Sula, Syariah, 218.

${ }^{25}$ Suma, Ekonomi, 184.
}

${ }^{23}$ Muhamad Amin Suma, Ekonomi \& Keuangan Islam(Cet.1; Tanggerang: Kholam 
Menurut Tjiptono dalam Selang, lokasi atau tempat seringkali ikut menentukan kesuksesan perusahaan, karena lokasi erat kaitannya dengan pasar potensial sebuah perusahaan.Disamping itu, lokasi juga berpengaruh terhadap dimensi-dimensi strategi seperti flexibility, competitive, positioning, dan focus.Fleksibilitas suatu lokasi merupakan ukuran sejauh mana perusahaan dapat bereaksi terhadap suatu perubahan situasi ekonomi.Keputusan pemilihan lokasi berkaitan dengan komitmen jangka panjang terhadap aspek-aspek yang sifatnya kapital intensif, maka ekonomi, demografi, budaya, dan persaingan di masa mendatang. ${ }^{26}$

Dalam menentukan place atau saluran distribusi, perusahaan harus mengutamakan tempat-tempat yang sesuai dengan target market sehingga dapat efektif dan efisien. ${ }^{27}$

\section{d. Promosi (Promotion)}

Promosi merupakan suatu bentuk komunikasi pemasaran.Merupakan aktivitas perusahaan yang berusaha menyebarkan informasi, mempengaruhi atau membujuk, atau mengingatkan pasar sasaran atas

${ }^{26}$ Christian A.D Selang, Bauran Pemasaran (Marketing mix) pengaruhnya Terhadap Loyalitas Konsumen Pada Fresh Mart Bahu mal Manado, http://www. Ejournal.unsrat.ac.id/ Jurnall Risat Ekonomi, manjemn, Bisnis dan Akutansi/ (1-3-2013), (Diakses 5 Mei 2018)

\footnotetext{
${ }^{27}$ Kertajaya, Sula, Syariah, 219.
}

lembaga dan produknya agar bersedia menerima, membeli dan loyal kepada produk yang ditawarkan perusahaan yang bersangkutan. ${ }^{28}$

Tujuan utama dari promosi adalah menginformasikan, mempengaruhi, dan membujuk serta mengingatkan pelanggan sasaran tentang perusahaan dan bauran pemasarannya. Apabila tujuan utama promosi telah terlaksana maka hal tersebut akan menciptakan loyalitas konsumen yang dimana ketika loyalitas konsumen telah terbentuk akan membuat basis perusahaan itu menjadi semakin kuat. ${ }^{29}$

Menurut Kertajaya dan Sula, promosi yang berlandaskan syariah haruslah menggambarkan secara rill apa yang ditawarkan dari produk-produk atau servisservis perusahaan tersebut. Promosi yang tidak sesuai dengan kualitas atau kompetensi, contohnya promosi yang menampilkan imajinasi terlalu tinggi bagi konsumennya, adalah termasuk dalam praktik penipuan atau kebohongan. ${ }^{30}$

\footnotetext{
${ }^{28}$ Buchari Alma dan Ratih Hurriati, Manajemen Corporate Strategi \& Pemasaran jasa Pendidikan (Fokus Pada Mutu Pelayanan Prima) (Bandung: Alfabeta, 2008), 166.
}

${ }^{29}$ Parys Laily Nasution, Analsis Pengaruh Strategi Bauran Pemasaran Terhadap Kepuasan Mahasiswa Dalam Memilih Kuliah DI Business Colleg Lembaga Pendidikan dan Pengembangan Profeisi Indonesia (LP3I) Medan, Tesis, (Universitas Sumatera Utara, Medan, 2007), (Diakses 19 Mei 2018).

\footnotetext{
${ }^{30}$ Kertajaya, Sula, Syariah, 218.
} 


\section{$2.2 \quad$ Hipotesis}

Berdasarkan kerangka berfikir di atas, maka hipotesis dalam penelitian ini adalah sebagai berikut:

H1 : Diduga Produk berpengaruh terhadap terhadap keputusan pembelian mahasiswa IAIN Palu pada Kedai KOPMA Al-Iqtishad IAIN Palu.

H2 : Diduga Harga berpengaruh terhadap terhadap keputusan pembelian mahasiswa IAIN Palu pada Kedai KOPMAAl-Iqtishad IAIN Palu.

H3 : Diduga Lokasi berpengaruh terhadap terhadap keputusan pembelian mahasiswa IAIN Palu pada Kedai KOPMAAl-Iqtishad IAIN Palu.

H4 : Diduga Promosi berpengaruh terhadap terhadap keputusan pembelian mahasiswa IAIN Palu pada Kedai KOPMAAl-Iqtishad IAIN Palu.

\section{METODE PENELITIAN}

Penelitian ini menggunakan pendekatan kualitatif ${ }^{31}$ dengan pendekatan

\footnotetext{
${ }^{31}$ Miller, K. (2001). Quantitative Research Method in The New Hanbook of Organziational Communication: Advances in Theory, Research and Methods by frederick M. Jablin and Linda L. Putnam (Editors), London : Sage Publications.
}

survey $^{32}$. Kegiatan penelitian meliputi data, analisis, dan interpretasi tetang arti dari data yang diperoleh, instrument penelitian ini menggunakan kuesioner. Penelitian ini juga dimaksud untuk mengetahui pengaruh kualitas dan desain produk terhadap minat beli.

Sampel pada penelitian ini adalah sebagian dari mahasiswa IAIN Palu dari angkatan 2014 sampai dengan 2017. Untuk menentukan jumlah sampel yang diperlukan, maka peneliti menggunakan rumus slovin. Jumlah sampel semuanya adalah 98 orang.

Alat ukur dalam penelitian biasanya dinamakan instrument penelitian. Jadi instrumen penelitian ini adalah kuesioner yang digunakan mengukur fenomena alam maupun sosial yang diamati. ${ }^{33}$ Karena instrumen penelitinan akan digunakan untuk melakukan pengukuran dengan tujuan menghasilkan data kuantitatif yang akurat, maka setiap instrumen harus mempunyai skala. Penelitian ini menggunakan skala likert. Data diolah dengan menggunakan aplikasi statistic SPSS.

\section{HASIL DAN PEMBAHASAN}

\footnotetext{
${ }^{32}$ Boose, J. H. (1989). A survey of knowledge acquisition techniques and tools. Knowledge Acquisition, 1(1), 3-37. doi: https://doi.org/10.1016/S1042-8143(89)80003-2

${ }^{33}$ Sugiyono, Metode Penelitian Kombinasi, (Bandung: CV Alfabeta, 2015), h.136.
} 


\subsection{Deskrpsi Kuesioner dan Responden}

Deskripsi kuesioner dan responden digunakan untuk menggambarkan keadaan atau kondisi kuesioner dan responden sehingga dapat memberikan informasi tambahan serta memahami hasil-hasil penelitian. Penyajian data deskripsi penelitian bertujuan agar dapat dilihat dari data penelitian tersebut serta hubungan anatara variabel yang digunakan dalam penelitian dengan jumlah responden.

a. Deskrpis Kuesioner Yang Dibagi

Penelitian ini dilakukan pada Kedai 2.2 KOPMA Al-Iqtishad IAIN Palu yang a. beralamatkan di Institut Agama Islam Negeri (IAIN) Palu, di Jl. Diponegoro No. 23 Palu. Data penelitian menggunakan instrumen kuesioner yang dibagikan kepada mahasiswa IAIN Palu yang terdiri dari tiga fakultas sebagai sampel penelitian. Kuesioner disebarkan oleh peneliti kepada sampel yang diteliti dengan perincian sebagai berikut:

Tabel 1. Distribusi Kuesioner

\begin{tabular}{|c|c|c|c|c|}
\hline 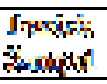 & 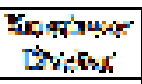 & 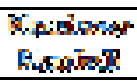 & 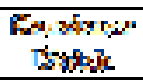 & 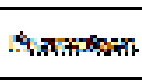 \\
\hline sí & * & as & $\approx$ & 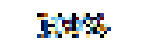 \\
\hline
\end{tabular}

Sedangkan distribusi responden menurut fakultas dapat digambarkan sebagai berikut:

Tabel 2. Responden Menurut Fakultas

\begin{tabular}{|c|c|c|c|}
\hline 2 & 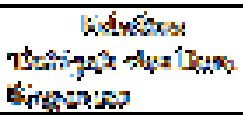 & Lytasts & 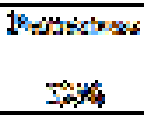 \\
\hline 3 & 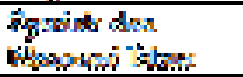 & 锉 & Whe \\
\hline 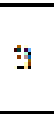 & 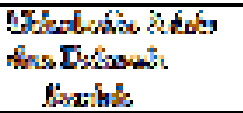 & $\begin{array}{l}\text { I: } \\
3 \%\end{array}$ & 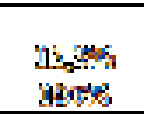 \\
\hline
\end{tabular}

Pada tabel 2 menunjukkan jumlah responden dari setiap fakultas, dimana responden terbanyak berasal dari Fakultas Tarbiyah dan Ilmu Keguruan yaitu sebanyak 51 orang (52\%), kemudian Fakultas Syariah dan Ekonomi Islam sebanyak 32 orang(32,7\%), dan Fakultas Ushuludin Adab dan Dakwah sebanyak 15 orang(15,3\%).

Hasil Uji Instrumen

a. Uji Validitas

Uji validitas yaitu mengkorelasikan masing-masing pernyataan dengan jumlah skor untuk masing-masing variabel. Syarat minimum untuk memenuhi syarat adalah apabila $r=0,3$ jadi apabila korelasi antar butir dengan skor total kurang dari 0,3 maka instrumen tersebut tidak valid. ${ }^{34}$

Tabel 3. Hasil Uji Validitas

\footnotetext{
${ }^{34}$ Sugiyono, Metode Penelitian Kuantitatif, Kualitatif dan $R$ an D, (Cet.XIII; Bandung: CV. Alfabeta, 2011), h 20.
} 


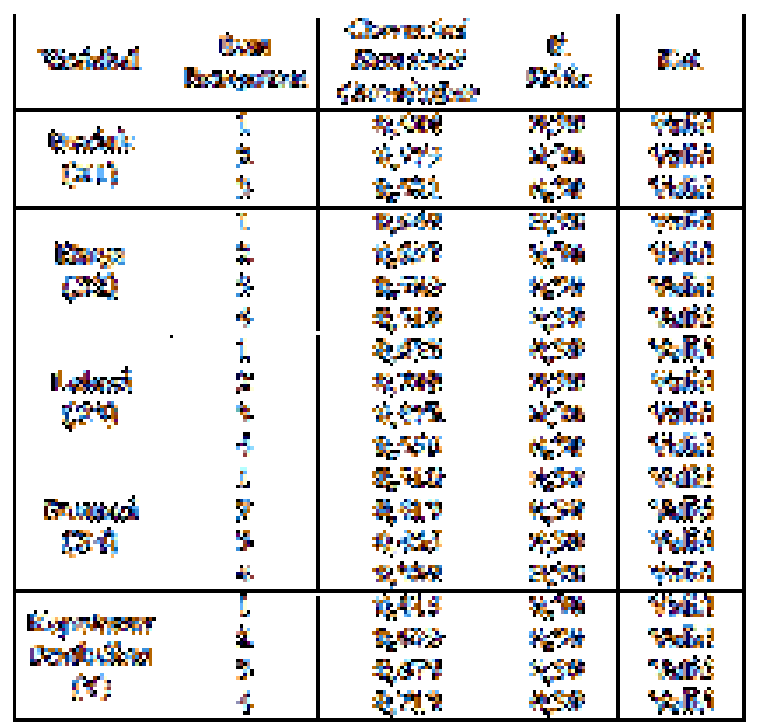

Dari tabel 3 menunjukkan bahwa nilai $r_{\text {hitung }}$ pada kolom Corrected Item Total Correlation untuk masing-masing item memiliki $\mathrm{r}_{\text {hitung }}$ lebih besar dan positif dari 0,3 yang artinya item pernyataan dalam variabel X1, X2, X3, X4, dan Y adalah valid. Sehingga pernyataan kuesioner yang dinyatakan valid dapat digunakan dalam pengumpulan data penelitian.

b. Uji Reliabilitas

Pengujian reliabilitas dilakukan 2.3 dengan internal consistensy atau derajat ketepatan jawaban. Untuk penelitian ini digunakan Statistical Packaged For social Sciences (SPSS) sebagai alternatif pengujian reliabilitas untuk mengetahui konsistensi hasil sebuah jawaban tentang tanggapan responden. Untuk melakukan pengujian reliabititas penulis menggunakan SPSS versi 21.0, yaitu dalam mengukur reliabilitas disini menggunakan uji statistik Cronbach
Alpha $(\alpha)$, yang mana satu variabel dikatakan reliabel jika memiliki Cronbach Alpha lebih dari 0,60 $(>0,60) .{ }^{35}$

Instrumen yang sudah dipercaya, yang reliabel, akan menghasilkan data yang dapat dipercaya pula. Apabila datanya memang sesuai dengan kenyataanya, maka berapa kalipun diambil tetap akan sama. Alat ukur itu reliabel bila alat itu dalam mengukur suatu gejala pada waktu yang berlainan senantiasa menunjukan hasil yang sama.

Hasil pengujian reliabilitas instrumen menggunakan alat bantu oleh statistik SPSS versi 21.0 for windows dapat diketahui dalam tabel berikut:

Tabel 4. Hasil Uji Reliabilitas

\begin{tabular}{|c|c|c|c|}
\hline 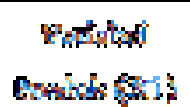 & 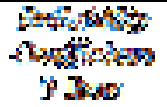 & 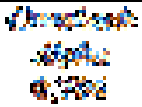 & 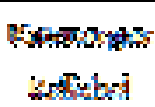 \\
\hline 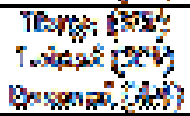 & 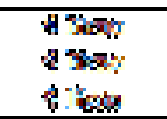 & 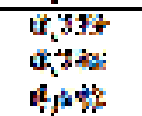 & 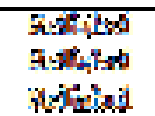 \\
\hline 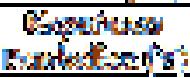 & 175 & $5.78 \%$ & की \\
\hline
\end{tabular}

\subsection{Hasil Uji Hipotesis}

Uji F (Uji Simultan)

Pengujian ini ingin diketahui apakah variabel independen $(\mathrm{X})$ berpengaruh secara bersama-sama memberikan kontribusi secara signifikan terhadap variabel dependen.

Tabel 5. Uji Simultan 


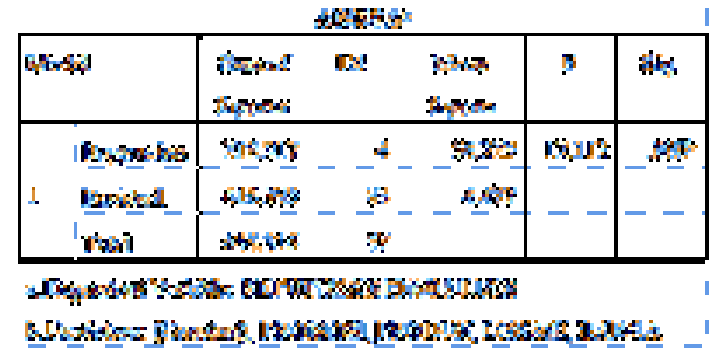

Berdasarkan hasil uji Anova (Analisis Of Varians), atau $\mathrm{F}$ tes diperoleh nilai $F_{\text {hitung }}$ sebesar $12,11>F_{\text {tabel }} 2.46$ dengan nilai Sig sebesar 0,000 lebih kecil dibandingkan alpha 0,05. Dengan demikian hasil ini memberikan makna bahwa variabel Produk (X1), Harga (X2), Lokasi (X3), dan Promosi (X4) secara simultan berpengaruh signifikan terhadap Keputusan Pembelian (Y).

\section{a. Uji T (Parsial)}

Uji hipotsis dilakukan dengan Uji T (parsial) digunakan untuk menguji apakah sebuah variabel independen (variety seeking dan fitur produk) benar-benar memberikan kontribusi terhadap variabel dependen (brand switching handphone). Berikut di bawah ini tabel hasil uji $\mathrm{T}$ pada tabel coeficients.

Tabel 6. Hasil Uji T (Parsial)

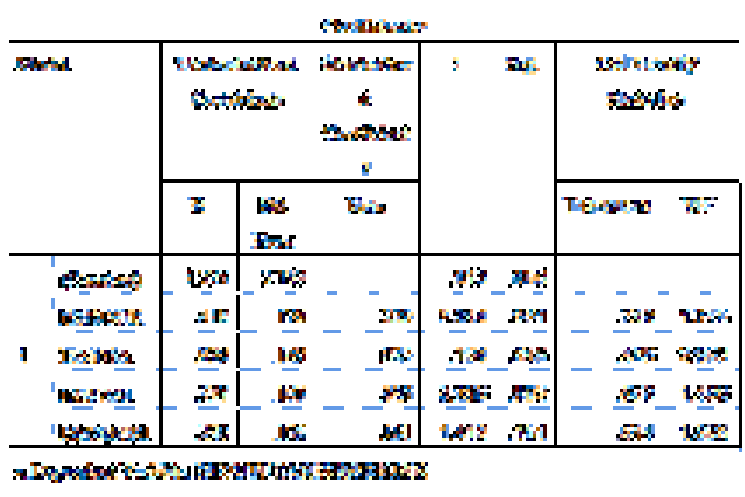

Berdasarkan hasil perhitungan statistik uji $\mathrm{T}$ dari 4 variabel independen yang dimasukkan dalam model regresi terlihat bahwa:

a. Produk (X1) diperoleh nila thitung 2,344> $\mathrm{t}_{\text {tabel }} 1,985 \mathrm{dan}$ memilki nilai signifikan (sig) 0,02 pada tabel coefficients dengan nilai $\alpha$ (tingkat siginfikan) 0,05 . Artinya $0,02<0,05$. Dengan nilai ini memberikan makna bahwa secara parsial variabel Produk (X1) memberikan pengaruh secara siginfikan terhadap Keputusan Pembelian (Y). Adapun besaran pengaruhnya dapat dilihat pada kolom Beta. Besaran pengaruh variabel X1 terhadap variabel Y yaitu 22,9\%.

b. Harga (X2) diperoleh nilai t hitung $0,194<$ $t_{\text {tabel }} 1,985$ dan nilai signifikan (sig) 0,846 lebih besar dari nilai $\alpha$ 0,05. Artinya 0,846> 0,05. Dengan nilai ini memberikan makna bahwa variabel harga (X2) tidak memberikan pengaruh signifikan terhadap keputusan pembelian (Y). Adapun besaran pengaruhnya dapat dilihat pada kolom Beta. Besaran 
pengaruh variabel X2 terhadap variabel $\mathrm{Y}$ yaitu $2,3 \%$.

c. Lokasi (X3) diperoleh nilai $t_{\text {hitung } 3,265>}$ $t_{\text {tabel }}$ 1,985 dan nilai signifikan (sig) 0,002 lebih kecil dari nilai a 0,05. Artinya $0,002<0,05$. Dengan nilai ini memberikan makna bahwa variabel lokasi (X3) memberikan pengaruh yang positif dan signifikan terhadap keputusan pembelian (Y). Adapun besaran pengaruhnya dapat dilihat pada kolom Beta. Besaran pengaruh variabel X3 terhadap variabel Y yaitu 33,5\%.

d. Promosi (X4) diperoleh nilai $t$ hitung 1,412 $<t_{\text {tabel }} 1,985$ dan nilai signifikan (sig) 0,161 lebih besar dari nilai a 0,05 . Artinya $0,161>0,05$. Dengan nilai ini memberikan makna bahwa variabel promosi (X4) tidak memberikan pengaruh yang signifikan terhadap keputusan pembelian (Y). Adapun besaran pengaruhnya dapat dilihat pada kolom Beta. Besaran pengaruh variabel X4 terhadap variabel Y yaitu 16,1\%.

e. Jadi, dari beberapa variabel bauran1. pemasaran yang diteliti. Maka, variabel bauran pemasaran yang paling besar pengaruhnya terhadap keputusan pembelian Mahasiswa IAIN Palu pada Kedai KOPMA Al-Iqtishad IAIN Palu adalah variabel lokasi dengan besaran pengaruh yaitu $33,5 \%$.

\subsection{Pembahasan}

Hasil pengujian dengan menggunakan analisis regresi berganda dengan bantuan SPSS 21 for Windows, pengaruh bauran pemasaran terhadap keputusan pembelian mahasiswa IAIN Palu pada kedai KOPMA Al-Iqtishad IAIN Palu menunjukkan bahwa secara simultan memiliki pengaruh positif terhadap keputusan pembelian mahasiswa. Begitu pula dengan pengaruh masing-masing variabel secara parsial masing-masing memiliki pengaruh dengan besaran pengaruh yang berbeda.

Berdasarkan hasil uji Anova analisis data, dengan hasil $F_{\text {hitung }}$ 12.11 $>F_{\text {tabel }} 2.46$ dengan nilai Sig sebesar 0,000 lebih kecil dibandingkan alpha 0,05. Dengan demikian hasil ini memberikan makna bahwa variabel Produk (X1), Harga (X2), Lokasi (X3), dan Promosi (X4) secara simultan berpengaruh signifikan terhadap Keputusan Pembelian Mahasiswa(Y).

Pengaruh Produk Terhadap Keputusan Pembelian Mahasiswa

Berdasarkan hasil uji statistik diperoleh nila $t_{\text {hitung }} 2,344>t_{\text {tabel }} 1,985$ dan memilki nilai signifikan (sig) 0,02 pada tabel coefficients dengan nilai $\alpha$ (tingkat siginfikan) 0,05. Artinya 0,02 $<0,05$. Dengan nilai ini memberikan makna bahwa secara parsial variabel Produk 
memberikan pengaruh secara siginfikan terhadap Keputusan Pembelian (Y). Adapun besaran pengaruhnya dapat dilihat pada kolom Beta. Besaran pengaruh variabel X1 terhadap variabel Y yaitu 22,9\%. Hasil ini dapat memberikan gambaran bahwa reponden (mahasiswa) memandang bahwa produk yang dimiliki dan ditawarkan oleh Kedai KOPMA sudah mampu mempengaruhi secara signifikan keputusan mahasiswa untuk melakukan pembelian di Kedai KOPMA Al-Iqtishad IAIN Palu.

Sesuai dengan hasil jawaban responden yang ada bahwa, 55 responden atau $56,1 \%$ yang setuju dengan pernyataan bahwa makanan dan minuman yang disajikan Kedai KOPMA terbilang higenis dan bersih dan juga terdapat 55 responden atau $56,1 \%$ yang setuju dengan pernyataan bahwa menu yang disajikan sesuai dengan yang ditawarkan. Hal ini dapat dianggap telah menjadi dorongan para mahasiswa melakukan keputusan pembelian di Kedai KOPMA Al-Iqtishad IAIN Palu.

Hasil penelitian sejalan dengan penelitian yang dilakukan oleh Anggoro Dwi Kurniawan, yang menunjukkan bahwa2. variabel produk berpengaruh terhadap keputusan pembelian Pada Kedai Amarta Semarang. ${ }^{36}$

\footnotetext{
${ }^{36}$ Kurniawan, Analisis, 63.
}

Produk dalam Islam dapat juga menjadi faktor konsumen untuk melakukan keputusan pembelian terhadap suatu produk yang ditawarkan. Namun, dalam Islam produk yang ditawarkan kepada konsumen haruslah produk yang memiliki manfaat, memilki nilai guna, serta yang terpenting adalah halal dan thoyib untuk dikonsumsi. Sebagaimana terkandung dalam Q.S AlBaqarah ayat $173 .^{37}$

Islam pada dasarnya tidak melarang umatnya untuk melakukan produksi, namun Islam juga memberikan arahan bahwa didalam melakukan produksi harus terhindar dari aktivitas yang merugikan orang lain atau memproduksi barang atau produk yang diharamkan. ${ }^{38}$

Kesimpulan yang dapat diambil dari pemaparan di atas, baik dari hasil uji statistik maupun dari sudut pandang ekonomi syariah bahwa, produk dalam bauran pemasaran memilki pengaruh terhadap keputusan pembelian. Adapun besaran pengaruhnya atau sifat pengaruhnya (positif/negatif) itu bergantung pada seberapa sukses penerapannya dalam suatu perusahaan.

Pengaruh Harga Terhadap Keputusan Pembelian Mahasiswa

\footnotetext{
${ }^{37}$ Alma, Manajemen, 262.

${ }^{38}$ Faisal Badroen dkk, Etika Bisnis dalam Islam (Ed.I, Cet. Ke-2;Jakarta: KENCANA PRENADA MEDIA GROUP, 2006), 117.
} 
Berdasarkan hasil uji statistik diperoleh nilai $\mathrm{t}_{\text {hitung }} 0,194<\mathrm{t}_{\text {tabel }} 1,985$ dan nilai signifikan (sig) 0,846 lebih besar dari nilai $\alpha 0,05$. Artinya $0,846>0,05$. Dengan nilai ini memberikan makna bahwa variabel harga (X2) tidak memberikan pengaruh signifikan terhadap keputusan pembelian (Y). Adapun besaran pengaruhnya dapat dilihat pada kolom Beta. Besaran pengaruh variabel $\mathrm{X} 2$ terhadap variabel $\mathrm{Y}$ yaitu 2,3\%..Hasil ini dapat memberikan gambaran bahwa reponden (mahasiswa) memandang bahwa harga produk yang ditawarkan oleh Kedai KOPMA belum mampu mempengaruhi secara signifikan keputusan mahasiswa untuk melakukan pembelian di Kedai KOPMA Al-Iqtishad IAIN Palu.

Sesuai dengan hasil jawaban responden yang ada bahwa, 20 orang responden atau $20,4 \%$ yang kurang setuju dengan pernyataan bahwa harga menu yang ditawarkan Kedai KOPMA tetap atau tidak berubah dan juga terdapat 14 responden atau $14,3 \%$ yang kurang setuju dengan pernyataan bahwa harga yang ditawarkan Kedai KOPMA tergolong terjangkau. Hasil ini membuktikan bahwa harga yang ditawarkan Kedai KOPMA belum cukup terjangkau di kalangan mahasiswa IAIN3. Palu, sehingga mahasiswa tidak menjadikannya suatu alternatif untuk melakukan keputusan pembelian di Kedai KOPMA Al-Iqtishad IAIN Palu.
Hasil penelitian ini didukung juga oleh hasil penelitian sebelumnya yang dilakukan oleh Ita Khairunnisa, bahwa variabel harga tidak berpengaruh terhadap keputusan mahasiswa dalam memilih Perguruan Tinggi IAIN Palu.

Harga di dalam islam yang dapat mempengaruhi keputusan konsumen untuk melakukan keputusan pembelian yaitu, harga yang didasari oleh nilai kejujuran dan keadilan, yaitu harga yang sesuai dengan kalitas produk dan harga yang tidak berlebihan. Karena harga yang didasari pada nilai itu tidak akan mengecewakan konsumen. ${ }^{39}$ Sebagaimana yang terkandung dalam Q.S An-Nisa ayat 29.

Berdasarkan pemaparan di atas, baik dari hasil uji statistik maupun dari sudut pandang ekonomi syariah dapat disimpulkan bahwa, harga dalam bauran pemasaran memilki pengaruh terhadap keputusan pembelian. Adapun besaran pengaruhnya atau sifat pengaruhnya (positif/negatif) itu bergantung pada seberapa sukses penerapannya dalam suatu perusahaan. Semakin baik penerapannya dalam suatu perusahaan maka akan semakin baik pengaruhnya.

Pengaruh Lokasi Terhadap Keputusan Pembelian Mahasiswa

\footnotetext{
${ }^{39}$ Kertajaya, Sula, Syariah, 218.
} 
Berdasarkan hasil uji statistik diperoleh nilai $\mathrm{t}_{\text {hitung }} 3,265>\mathrm{t}_{\text {tabel }} 1,985$ dan nilai signifikan (sig) 0,002 lebih kecil dari nilai $\alpha 0,05$. Artinya $0,002<0,05$. Dengan nilai ini memberikan makna bahwa variabel lokasi (X3) memberikan pengaruh yang positif dan signifikan terhadap keputusan pembelian (Y). Adapun besaran pengaruhnya dapat dilihat pada kolom Beta. Besaran pengaruh variabel X3 terhadap variabel Y yaitu 33,5\%. Hasil ini dapat memberikan gambaran bahwa reponden (mahasiswa) memandang bahwa lokasi Kedai KOPMA sudah mampu mempengaruhi keputusan mahasiswa untuk melakukan pembelian di Kedai KOPMA AlIqtishad IAIN Palu.

Sesuai dengan hasil jawaban responden yang ada bahwa, 42 responden atau $42,9 \%$ yang setuju dengan pernyataan bahwa Lokasi Kedai KOPMA terbilang strategis dan 44 responden atau 44,9\% yang setuju dengan pernyataan bahwa lokasi Kedai KOPMA mudah diakses/ mudah dijumpai. Hasil ini membuktikan bahwa lokasi Kedai KOPMA sudah cukup dekat dan mudah dijumpai, sehingga mahasiswa dapat menjadikannya suatu alternatif untuk melakukan keputusan pembelian di Kedai4. KOPMA Al-Iqtishad IAIN Palu.

Hasil penelitian ini mendukung penelitian sebelumnya yang dilakukan oleh Arum Puspa Utami, yang menyatakan bahwa variabel lokasi memberikan pengaruh positif terhadap keputusan pembelian konsumen di Minimarket KOPMA Universitas Yogyakarta.

Agar lokasi usaha dapat menjadi daya tarik konsumen untuk melakukan keputusan pembelian maka, dalam Islam pemilihan lokasi yang baik adalah salah satu hal penting yang harus diperhatikan oleh wirausaha atau pedagang. Agar usahanya dapat terlihat strategis dalam memperoleh pelanggan maka, terdapat beberapa pertimbangan yang akan dipikirkan untuk menetukan lokasi yang baik. Lokasi yang baik yang dimaksudkan disini adalah lokasi atau tempat usaha yang selalu dijaga kebersihan dan keindahannya. Jika lokasi atau tempat usaha bersih dan indah maka akan memberikan kenyamanan bagi konsumen. Hal itu dapat menjadi daya tarik konsumen untuk datang berkunjung atau bahkan bisa menjadi pelanggan. ${ }^{40}$ Selain itu, penentuan lokasi tersebut harus diperhatikan oleh pedagang karena tidak akan pernah lepas dari tanggungjawabnyaterhadap lingkungan dan sekitarnya, dengan melihat bahwa tidak akan merusak lingkungannya dan merugikan orang lain.

Pengaruh Promosi Terhadap Keputusan Pembelian Mahasiswa

\footnotetext{
${ }^{40}$ Mardani, Ayat-ayat, 89.
} 
Berdasarkan hasil uji statistik keputusan pembelian maka, sebagai diperoleh nilai $\mathrm{t}_{\text {hitung }} 1,412<\mathrm{t}_{\text {tabel }} 1,985$ dan nilai signifikan (sig) 0,161 lebih besar dari nilai $\alpha 0,05$. Artinya $0,161>0,05$. Dengan nilai ini memberikan makna bahwa variabel promosi (X4) tidak memberikan pengaruh yang signifikan terhadap keputusan pembelian (Y). Adapun besaran pengaruhnya dapat dilihat pada kolom Beta. Besaran pengaruh variabel X4 terhadap variabel Y yaitu 16,1\%. Hasil ini dapat memberikan gambaran bahwa reponden (mahasiswa) memandang bahwa promosi yang dilakukan oleh Kedai KOPMA belum mampu secara signifikan mempengaruhi keputusan mahasiswa untuk melakukan pembelian di Kedai KOPMA Al-Iqtishad IAIN Palu.

Sesuai dengan hasil jawaban responden yang ada bahwa, 24 responden atau $24,5 \%$ yang kurang setuju dengan pernyataan bahwa Kedai Kopma sering melakukan promosi melalui pamphlet maupun media lain. Hasil ini membuktikan bahwa promosi yang dilakukan oleh pihak Kedai KOPMA belum dilakukan secara optimal sehingga mahasiswa tidak menjadikannya suatu alternatif untuk melakukan keputusan pembelian di Kedai KOPMA Al-Iqtishad IAIN Palu.

Karena promosi merupakan hal penting yang dapat mempengaruhi keputusan konsumen untuk melakukan wirausaha atau pedagang muslim haruslah berlandaskan pada prinsip syariah saat melakukan promosi. Produk-produk yang ditawarkan kepada konsumen haruslah digambarkan sesuai kenyataan produk yang ada dan jangan berlebihan dalam melakukan promosi. Tidak dibenarkan melakukan kebohongan dalam promosi, hanya karena ingin menarik banyak konsumen. Jika kualitas produk tidak sesuai dengan promosi yang dilakukan maka itu sudah termasuk dalam hal kebohongan dan merugikan konsumen. Selain itu, konsumen juga akan merasa kecewa dan pada akhirnya tidak akan menggunakan produk yang sama lagi. ${ }^{41}$

\section{Kesimpulan}

Secara parsial variabel produk dan lokasi mempunyai pengaruh signifikan terhadap keputusan pembelian Mahasiswa IAIN Palu pada Kedai KOPMA Al-Iqtishad IAIN Palu, dengan besaran pengaruh produk $22,9 \%$ dan besaran pengaruh lokasi yaitu $33,5 \%$.

Secara serempak atau simultan variabel produk (X1), harga (X2), lokasi (X3), dan promosi (X4) berpengaruh terhadap keputusan pembelian mahasiswa (Y). Dimana besaran pengaruhnya dapat dilihat pada tabel model summary pada kolom Adjusted Rsquare yaitu sebesar 0,314

\footnotetext{
${ }^{41}$ Kertajaya, Sula, Syariah, 218.
} 
atau $31,4 \%$, dan selebihnya dipengaruhi oleh variabel independen lain yang tidak termasuk dalam penelitian ini.

Adapun variabel dari bauran pemasaran yang paling besa rpengaruhnya terhadap keputusan pembelian Mahasiswa IAIN Palu pada Kedai KOPMA Al-Iqtishad IAIN Palua dalah variabel lokasi dengan besaran pengaruh yaitu $33,5 \%$.

\section{Daftar Pustaka}

Abdul, Syekh Halim Hasan Binjai. Tafsir AlAhkam,Ed.1. Cet. Ke-1; Jakarta: Kencana, 2006.

Alma, Buchari. Dan Doni Juni Priansa. Manajemen BisnisSyariah Menanamkan NilaidanPraktik Syariah dalam Bisnis Kontemporer. Edisi Revisi; Bandung: Alfabeta, 2014.

,Ratih Hurriati. Manajemen Corporate Strategi\& Pemasaranjasa Pendidikan Fokus Pada Mutu Pelayanan Primai. Bandung: Alfabeta, 2008.

Manajemen Bisnis Syariah. Bandung: Alfabeta, 2009

Amin Suma, Muhamad. Ekonomi \& Keuangan Islam.Cet.1;Tanggerang: Kholam Publishing, 2008.

Badroen, Faisaldkk, Etika Bisnis dalam Islam, Ed. I, Cet. Ke-2; Jakarta: Kencana Prenada Media Group, 2006.

Bin Hajjaj,Muslim. Shahih Muslim. Berut: Darul Fikr, 1992. 11, diterjemahkan oleh A. Razak dan Rais Lathief,
Terjemahan

Shahih

Muslim.Cet.III;Jakarta: Pustaka Al Husna, 1988.

Budianto,Apri. Manajemen Pemasaran. Yogyakarta: Penerbit Ombak, 2015.

Chaudry, Muhammad Syarif, Sistem Ekonomi Islam, Ed. I; Jakarta, Prenada Media Group, 2012.

Cotler dan Amstrong, Philip. PrinsipPrinsip Pemasaran Jilid I Edisi XII Diterjemahkan Oleh Bob sabran. Jakarta: Erlangga, 2008.

Darmmesta, Basu Swashta. dan Hani Handoko, Manajemen Pemasaran AnalisisPerilaku Konsumen. Yogayakarta: BPFE, 2013.

Ghazaly, Abdul rahmandkk, Fiqh Muamalat, Ed. I; Jakarta: PRENADA MEDIA GROUP, 2010.

Ghozali, Imam. Aplikasi Analisis Nultivariate Dengan Program IBM SPSS 21.Cet. VII; Semarang: Badan Penerbit UNDIP, 2013.

Hasan,Irmayanti, Manajemen Operasional Perspektif Integratif , Malang, UIN Maliki Press, 2011

Indrawan, Rullydan PopyYaniawati, Metode Penelitian. Cet.I; Bandung: PT. Rafika Aditama, 2014.

J. Setiadi, Nugoroho. Perilaku Konsumen. Edisi revisi; Jakarta: Kencana Prenada Grup, 2010.

Kasmir. Kewirausahaan. Ed. 1; Jakarta: PT Raja Grafindo Persada, 2006.

.Pemasaran Bank. Ed.Rev.Cet-3; Jakarta: Kencana Prenada media Group, 2004. 
Kemetrian Agama Republik Indonesia. AlQur'an dan Terjemahan. Surabaya; Pustaka Agung Harapan, 2011.

Kotler, Phlipdan Kevin Lane Keller, Manajemen Pemasaran. Cet.XIII; Jakarta: Erlangga, 2009.

Mardani. Ayat- Ayat dan Hadis Ekonomi Syariah.Ed.1. cet.1; Jakarta: Rajawali Pers, 2011.

Nurrianto, Al Arif, M. dan Euis Amalia, Teori Mikro Ekonomi. Jakarta: Kencana, 2010.

Riduan, Adnun Rusyana dan Enas,Cara mudah belajar SPSSS 17.0 dan Aplikasi Statistik Penelitian. Cet.III; Bandung: ALFABETA, 2013.

Riduan. Penelitian untuk Guru, Karyawan dan Peneliti Pemula. Bandung: ALFABETA, 2012.

Sarjono, Haryadi dan Wilda Julianti, SPSS vs LISREL Sebuah Pengantar Aplikasi
Untuk Riset.Jakarta: Salemba Empat, 2011.

Siregar, Sofyan. Metode Penelitian Kuantitaif (dilengkapi denganperbandingan perhitungan manual dan SPSS).Jakarta: Kencana, 2013.

.Statistika Deskriptif untuk Penelitian Dilengkapi Perhitungan Manual dan Aplikasi SPSS Versi 17.Ed.1. Cet. 5; Jakarta: RajawaliPers, 2016.

Sugiyono. Metode Penelitian Kuantitatif Kualitatifdan $R \& D . \quad$ Bandung: ALFABETA, 2013.

Supardi, Metode Penelitian Ekonomidan Bisnis. Yogyakarta: UII Perss, 2005.

Taniredja, Tukiran dan Hidayati Mustafidah, Penelitian Kuantitatif Sebuah Pengantar. Purwokerto: ALFABETA, 2011. 